Published as:

Meghraoui, M., Gomez, F., Sbeinati, R., Van der Woerd, J., Mounty, M., Darkal, A. N., Radwan, Y., Layyous, I., Al-Najjar, H., Darawcheh, R., Hijazi, F., Al-Ghazzi, R., and Barazangi, M., 2003. Evidence for 830 years of seismic quiescence from palaeoseismology, archaeoseismology, and historical seismicity along the Dead Sea Fault in Syria, Earth Planet. Sci. Lett., 210, 35-52.

\title{
Evidence for 830 years of Seismic Quiescence from Palaeoseismology, Archaeoseismology and Historical Seismicity Along the Dead Sea Fault in Syria
}

Mustapha Meghraoui ${ }^{a}{ }^{*}$, Francisco Gomez $^{\mathrm{b}}$, Reda Sbeinati ${ }^{\mathrm{c}}$, Jerome Van der Woerd $^{\mathrm{a}}$, Michel Mouty ${ }^{\mathrm{d}}$, Abdul Nasser Darkal ${ }^{\mathrm{e}}$, Youssef Radwan ${ }^{\mathrm{c}}$, Ihsan Layyous $^{c}$, Haithem Al Najjar ${ }^{c}$, Ryad Darawcheh ${ }^{c}$, Fouad Hijazi ${ }^{\mathrm{d}}$, Riad AlGhazzi ${ }^{\mathrm{d}}$, and Muawia Barazangi ${ }^{\mathrm{b}}$

a EOST, Institut de Physique du Globe, Strasbourg, France

$b$ Institute for the Study of the Continents, Cornell University, Ithaca, New York 14853, USA

c Department of Geology, Atomic Energy Commission, Damascus, Syria

$d$ Department of Remote Sensing, Higher Institute for Applied Sciences and Technology, Damascus, Syria

e Department of Geology, Damascus University, Damascus, Syria

\footnotetext{
${ }^{*}$ Corresponding author :
}

Dr. Mustapha MEGHRAOUI

EOST-Institut de Physique du Globe de Strasbourg (UMR 7516)

5 , rue René Descartes

67084 Strasbourg cedex, France

Tel : +33(0)390240 111

Fax : +33(0)390240125

mailto:Mustapha@eost.u-strasbg.fr

http://eost.u-strasbg.fr/recherche/Equipe 7.html

\section{Earth \& Planetary Science Letters}

Submitted 7 September 2002

Revised 28 February 2003 


\begin{abstract}
The long historical records of earthquakes, the physical effects on ancient building structures and the palaeoseismology provide a unique opportunity for an interdisciplinary tectonic analysis along a major plate boundary and a realistic evaluation of the seismic hazard assessment in the Middle East. We demonstrate with micro-topographic surveys and trenching that the Dead Sea Fault (DSF) offsets left-laterally by $13.6 \pm$ $0.2 \mathrm{~m}$ a repeatedly fractured ancient Roman aqueduct (older than AD 70 and younger than AD 30). Carbon14 dating of faulted young alluvial deposits document the occurrence of three large earthquakes in the past 2000 years between AD 100 - 750, between AD 700 - 1030 and between AD 990 - 1210. Our study provides the timing of late Holocene earthquakes and constrains the $6.9 \pm 0.1 \mathrm{~mm} / \mathrm{yr}$. slip rate of the Dead Sea transform fault in northwestern Syria along the Missyaf segment. The antepenultimate and most recent faulting events may be correlated with the AD 115 and $\mathrm{AD} 1170$ large earthquakes for which we estimate $\mathrm{M}_{\mathrm{w}}=7.3-7.5$. The -830 years of seismic quiescence along the Missyaf fault segment implies that a large earthquake is overdue and may result in a major catastrophe to the population centres of Syria and Lebanon.
\end{abstract}

Key words: Active faulting, palaeoseismology, archaeoseismology, Dead Sea fault, 


\section{Introduction}

The long and rich cultural history of the eastern Mediterranean provides a special opportunity to incorporate physical and written history with earthquake geology for a more refined assessment of the seismic hazard. This approach is particularly important along the Dead Sea Fault (DSF) that corresponds to a major plate boundary (Fig. 1). However, the fault produced very few large continental earthquakes during the past eight centuries and this low level of seismic activity contrasts with written accounts of large devastating historical earthquakes [1].

The identification of seismic gaps and sequences along major fault systems requires an accurate knowledge of the seismicity catalogue ideally covering several large earthquakes. A time-averaged slip rate and an understanding of the related seismic cycle also contribute to better constrain the long-term faulting behaviour and recurrence interval of large seismic events. Hence, for equal rates of fault slip, the fault zone with the longest period of seismic quiescence is therefore considered as an earthquake-prone area where the hazard is a function of the elapsed time since the last seismic event and the physical dimensions of the related active fault segment.

The occurrence of large earthquakes and their associated damage in the Middle East are frequently reported during the Greek, Hebrew, Assyrian, Roman, Byzantine and Islamic times (Fig. 1 a and b) [1, 2, 3, 4]. In particular, Arab chroniclers describe with details main shocks, aftershocks, surface breaks and related damage distribution in the Middle East as early as the $7^{\text {th }}-8^{\text {th }}$ centuries $[4,5,6]$. Hence, the DSF provides a rare opportunity of correlating the historical descriptions of seismicity with field investigations in active tectonics, archaeoseismology and palaeoseismology.

Compared to other worldwide major strike-slip faults, the DSF is poorly understood as an active, seismogenic structure, and recent studies consider its northern section in Lebanon and Syria as inactive [7]. The late Quaternary tectonic activity along the DSF is characterized by (i) faulted young alluvial, colluvial and lacustrine deposits, (ii) deflected streams with consistent left-lateral displacements of tens to hundred metres, and (iii) evidence of large shutter-ridges and small pull-apart basins along strike. Both geologic and geodetic studies along the fault poorly constrain its kinematics as demonstrated by the wide range $2-10$ $\mathrm{mm} / \mathrm{yr}$ slip rates $[2,8,9,10,11,12]$.

Here, we present results from palaeoseismic and archaeoseismic investigations along the 70-km-long Missyaf segment of the northern section of the Dead Sea Fault. Historical Arabic documents allow to 
identifying an $\sim 830$ years seismic gap along the fault since the medieval time and help in the identification of damaged areas. Total station mapping, archaeoseismology and palaeoseismology provide new constraints on the seismic slip history during the past 2000 years along the fault and related seismic slip deficit. Finally, we discuss the consistency of the results, the fault segmentation and the slip model along the northern DSF. The multidisciplinary approach is emphasized for a realistic assessment of the seismic hazard along the DSF in the Middle East.

\section{Seismotectonic Setting}

The Dead Sea fault is a large continental strike-slip fault corresponding to the boundary between the Arabia and Africa plates. It is a left-lateral transform fault system, striking north-south and extending for $-1000 \mathrm{~km}$ from the Gulf of Aqaba to join the East Anatolian fault zone in southern Turkey (Fig. $1 \mathrm{a})$. The tectonic deformation associated with the DSF began in the early Pliocene with initiation of sea-floor spreading in the Red Sea $[13,14]$. The total left-lateral displacements along the DSF since the Pliocene and the initiation of sea floor spreading of the Red Sea are estimated to be $45 \mathrm{~km}$ to the south and $20-25 \mathrm{~km}$ to the north [15]. This difference in displacements may be explained by up to $20 \mathrm{~km}$ of shortening in the NESW trending Palmyride fold belt (Fig. 1 a) [16].

The low level of instrumental seismicity as observed from 1900 to present, and the scarce focal mechanisms along the central and northern DSF may suggest the idea that the DSF is moderately active (Fig. 1 a). However, this view is inconsistent with historical records of large, devastating earthquakes that attest to the activity and seismogenic potential (Fig. $1 \mathrm{~b}$ and Table 1), and with field observations, as described below. One of the best-documented and most recent event occurred in 1759 affecting the Bekaa Valley of Lebanon $(\mathrm{M}=7.4)$ with a rupture length of at least $100 \mathrm{~km}$ [3]. Other significant seismic events with probable surface faulting occurred in the past and ruptured different segments of the DSF [17]. Fault segments can be delimited according to the structural pattern of strike slip faults (e.g., main pull apart basins, steps, releasing and restraining bends). The northern DSF follows a relatively narrow trace between the Qalaat Al Hosn (Crak des Chevaliers) pull apart basin at the Syrian/Lebanese border to the south and in the Ghab Valley to the north (Fig. 1 c). Tectonic indicators include faulted alluvial fans, small and large stream deflections (tens to a few thousand metres), and the faulted Neogene and Quaternary Homs basaltic flows [18]. The Ghab 
Valley is a large pull-apart basin with up to $3.5-4 \mathrm{~km}$ of Pliocene and Quaternary fill [19]. Between the Ghab Valley and the Qalaat Al Hosn plain to the south the DSF forms the $70-\mathrm{km}$-long Missyaf segment. Historical data suggest that this section of the DSF may presently exhibit seismic quiescence and has not experienced a large earthquake since the $12^{\text {th }}-13^{\text {th }}$ century (Fig. 1 a and b).

\section{Historical Constraints of the Seismic Gap}

The historical record of seismicity of Syria and surrounding regions is one of the richest because of the numerous archaeological and historical sources dating back at least to BC $1365[1,4,5,6,20,21,22]$. Among the most important seismic events, a southward migrating sequence of large earthquakes took place in 1157, 1170 and 1202 along the Apamea, Missyaf, and Yammouneh segments of the DSF, respectively (Fig. 1 b). Several contemporaneous accounts describe the successive land shaking and related destructions of cities and villages. The 12 August 1157 (4 Rajab 552 Hegirian) earthquake is extensively described by Ibn El Qualansi (AD 1073 - 1160) who reported in detail a long period of seismic activity that affected Damascus and its surroundings regions between 28 September 1156 and 30 May 1159 [4]. In particular, El Qualansi mentions the different localities that were badly damaged by the main shock of 1157 . This description allows the assessment of the area of maximum damage, which constrains the earthquake parameters including the location of the epicentre area near Apamea (see Fig. 1 b) and the size that may reach the intensity IX (MKS scale). Reported details reflect the severity of the damage in a north-south elongated area that is consistent with El Qalansi report in the region of Apamea [4]. According to the distribution of maximum intensity, this event corresponds with the Apamea segment of the Dead Sea fault.

The 29 June 1170 (12 Shawwal 565 Hegirian) is reported primarily by Ibn El Athir $(1160$ - 1232) who describes in his book "El Kamil fi El Tarikh" more than 56 felt earthquakes in the region [23]. Despite his young age at the time of the 1170 earthquake, he kept in memory the "terrible" feeling of the quake and investigated later on during his travelling the earthquake damage. Ibn El Athir provides numerous detailed descriptions of strongly damaged cities such as Homs and Hama, which define an area of maximum damage in the region named "bilad el Firanj" literally "country of the Christians" or the crusaders region located in Crak des Chevaliers, Missyaf Fortress and Borj Safita (Fig. $1 \mathrm{~b}$ and c). These rich descriptions allow us to define the epicentre area with an estimated maximum intensity IX (MKS) between the well-known historical 
sites of Crak des Chevaliers and Missyaf Fortress [4], and to associate the AD 1170 event with the Missyaf segment of the DSF.

The 20 May 1202 earthquake took place mostly in Lebanon along the Yammouneh fault and has been extensively studied by Ambraseys and Melville (Fig. 1 b) [24]. The related surface rupture has been confirmed by palaeoseismic studies along the DSF near the Hula depression [9].

\section{Faulted Aqueduct and Holocene Palaeoseismic Timing at Al Harif Site}

Faulting of late Pleistocene and Holocene deposits, prominent fault scarps and shutter ridges with stream deflections, and faulted archaeological site provide the best location for palaeoseismic and archaeoseismic studies (Fig. 2). We conducted a combined study in archaeoseismology with excavation and detailed descriptions and mapping (with a total station) of the faulted aqueduct and the related evidence of deformation (Fig. 3 and 4). In parallel, palaeoseismic investigations consisted on a 20-m-long and 3.5-mdeep trench near the aqueduct and across the fault (Fig. $5 \mathrm{a}$ and b). The faulted aqueduct and the trench provide an interesting opportunity for investigating both the vertical and lateral offsets along the fault.

Archaeoseismic evidence: Of particular interest is the Al Harif shutter ridge site which shows an ancient aqueduct cut and displaced left-laterally by the fault (Fig. 2 and 3). This latter observation is apparently mentioned by Trifonov [18] in his work along the DSF, but curiously with only $0.6 \mathrm{~m}$ of displacement. An excavation, 8-m-long and 1-m-deep, along the western wall and at the intersection with the fault constrains the rupture pattern and stratigraphic age of the ancient building. The aqueduct wall foundation was found to end to the east against the discrete fault rupture while about $2.5 \mathrm{~m}$ of aqueduct wall above the ground is missing west of the fault (Fig. 3a and 4 a). At about $0.8-1 \mathrm{~m}$ depth, the wall is built into unit $\mathrm{d}$ and above unit e, which predate the aqueduct (see also trench log description below and in Fig. 5 b). The large fallen piece of wall (made of small stone pieces) found in between the two prominent eastern and western aqueduct sections, has no foundation, and most likely corresponds to a piece from the rebuilt eastern section that was rotated and dragged along the fault. According to local witnesses many of the aqueduct stones are reutilised for nearby fences.

The maximum age for the aqueduct may be bracketed from the age of the sedimentary units below its foundation and from early travertine accumulation on its wall. The 1 to 2 -m-deep excavation at the base of the aqueduct wall clearly show that the foundation stones are within unit $d$ and rest on the uppermost 
layers of unit e (BC 210 - AD 30, 2 $\sigma$ calibrated age, Table 2). The maximum possible age of the aqueduct is best defined by the minimum age of uppermost deposits of unit e, AD 30. In addition, organic fractions extracted from two early sections of cores of the $\sim 0.40$-m-thick travertine deposits on the aqueduct wall yield nearly identical radiocarbon calibrated ages of AD $80-240$ and AD $70-230$. These travertine ages indicate a building period younger than AD 70. Hence, the initial building of the aqueduct can be bracketed between $\mathrm{AD} 30$ and $\mathrm{AD} 70$ and may probably correspond to the early Roman period in the Middle East (post BC 64).

A detailed topographic survey of the area around the aqueduct accompanies the detailed mapping of the aqueduct itself (one point measured every $0.5 \mathrm{~m}$ at the base and on the top of each wall face). The straight original shape of the building is attested by: (i) The linear and orthogonal foundation of the aqueduct wall immediately west of the fault (Fig. 3 and 4 a), (ii) The warped section east of the fault zone with rotated blocks and the dragged and fallen block, (iii) The ruptured travertine filling previous ruptures and cracks at the warped section (Fig. 4 b), (iiii) The two $\sim 20$-m-long and linear parallel sections of the aqueduct and related bridge. Projecting the aqueduct walls into the N 07E striking DSF displays a total left-lateral displacement of $13.6 \pm 0.2 \mathrm{~m}$ between the two pieces of the faulted aqueduct (Fig. $3 \mathrm{a}$ and b). In addition, the eastern warped wall shows a deflection of $3.9 \pm 0.2 \mathrm{~m}$ reaching $4.3 \pm 0.2 \mathrm{~m}$ when projected on the fault line (Fig. 3 a). This observation suggests 4.0 to $4.5 \mathrm{~m}$ left-lateral coseismic slip for the successive faulting events. Furthermore, the aqueduct is built on a bridge across the river, which displays at least two kinds of building stones suggesting rebuilding episodes. At the warped section, the numerous ruptured stones and cracks filled with brecciated and ruptured travertine indicate at least two episodes of deformation, indicating the abandonment of the aqueduct before the third event (Fig. 4 b). Rebuilt phases and cracks in travertine help in documenting the two first successive faulting events. It is likely that no travertine accumulation and rebuilding phase were anymore present after the second event.

Palaeoseismic trenching: The trench was dug in an alluvial terrace made of $4-5 \mathrm{~m}$ thick young sediments likely deposited by the nearby stream (Fig. 2, 3 and 5 a). The terrace rests approximately $5 \mathrm{~m}$ above the current streambed that flows across bedrock forming a dogleg offset of about $-200 \mathrm{~m}$. The trench walls expose sediments with different units illustrated by the log of Fig. 5 b. The trench bottom shows unit g, which consists on a massive, and plastic grey clay with some scattered breccias elements (mainly limestone). Unit $\mathrm{f}$ that covers unit $\mathrm{g}$ corresponds to a massive alluvial deposit with 1 to 2 -m-thick dark-brown sandy clay 
with breccias and rounded gravels and about $0.3-\mathrm{m}$-thick stratified pebbles. Deposit $\mathrm{f}$ shows a dramatic increase of its thickness to the east and the coarse gravel and pebble at its base suggest the location of an old channel. Unit e is $0.10-\mathrm{m}$ to 0.25 -m-thick dark-brown silt-clay. Well-sorted reddish fine gravels with cross bedding correspond to unit $\mathrm{d}$ that shows a variable thickness from 0.10 to $0.50 \mathrm{~m}$ due to the above truncation surfaces. Unit $\mathrm{c}$ is a thin sandy-clay deposit with a limited extension below unit $\mathrm{b}$ that corresponds to a chaotic deposit with mixed gravels and clastic (limestone) elements in a sandy clay matrix. Unit a that shows clearly stratified gravels and pebbles at its base truncates units $\mathrm{b}$ and $\mathrm{d}$ all along the wall. Unit a also forms a 0.20 to 0.40 -m-thick coarse gravel deposits on which develops the present soil. All interfaces of units above $\mathrm{f}$ are erosion surfaces except between $\mathrm{b}$ and $\mathrm{c}$.

Pottery shards and detrital fragments of charcoals are well distributed through the trench walls and were collected for dating (Table 2). 8 samples of charcoal from the north wall were dated using the $\mathrm{C}^{14} \mathrm{AMS}$ methods and calibrated with $2 \sigma$ age range using Oxcal v3.5 [25]. 6 of the collected charcoal fragments were of large size and angular shape (suggesting limited transport or initial deposition and no reworking) and revealed a fairly large amount of carbon fraction after laboratory treatment (Table 2). In Fig. 5 b, samples of units a, c, d, e and f gave 2, 5.9, 4.3, 2 and $4.1 \mathrm{mg}$ of carbon content, respectively, and the $\Delta \mathrm{C}^{13}$ attests for the good-quality of radiocarbon dating. Only two samples show out of sequence ages in units $b$ and d but they yielded 1 and $0.3 \mathrm{mg}$ of carbon, respectively (see BC 3490 - 3098 and BC $1010-791$ in Figure 5 b and Table 2) and are therefore interpreted as reworked detrital charcoal in mixed deposits. Additional constraints on the timing of individual palaeoseismic events is provided by considering the stratigraphic superposition and applying the Bayes analysis (conditional probability for the stratigraphic succession and datations) to the age ranges obtained from calibration of radiocarbon ages (Table 3) [27].

Both walls reveal a 2-meter wide fault zone that consists on intensely sheared sedimentary deposits (Fig. $5 \mathrm{a}$ and b). No other shear zone or minor faulting exists in trench walls (the northern trench wall join the edge of the river and exhibits a large stratigraphic section). While motion on the fault is mostly left lateral, it bears a small but significant vertical component at this site as pointed out by the vertical offset of $1 \mathrm{~m}$ of units e and $\mathrm{d}$ in the trench. Some fault strands are clearly truncated by the successive deposits that register the faulting episodes (Fig. 6 a and b). Furthermore, the intense deformational structures visible along the shear zone and the numerous rupture strands that affect the successive sedimentary units testify that the 
palaeoearthquakes were large faulting events. The successive truncated fault strands that can be recognized in Fig. 5 b represent, therefore, past large earthquakes in the trench wall:

Event Z: Unit a caps the entire fault zone and post-dates all coseismic movements which appear to have occurred before $\mathrm{AD} 1030$ - 1260; the $\mathrm{AD} 1260$ provide a minimum age for unit a and a maximum age for the most recent large earthquake along the fault. The most recent large seismic event can be defined within the large age bracket between units a and c. After Bayesian analysis, this event is constrained at the $95 \%$ confidence limit by radiocarbon dating between AD 990 and AD 1210 (Table 3). This result is consistent with the occurrence of the historical earthquake of 29 June 1170 along the Missyaf fault segment.

Event $Y$ : The penultimate event is visible immediately west of the shear zone where unit $\mathrm{b}$ truncates two fault strands and related shear zone that affect unit d. Unit d is dated at AD 680 - 890. Applying Bayesian analysis determines the occurrence of a large event between AD 700 and AD 1030 (Table 3). This time range of about 340 years is quite large. The historical seismicity, however, allows us to infer that the earthquake took place during the Byzantine time or at the very beginning of the Islamic time ( $>$ AD 680). Several candidate historical earthquakes [see ref. 4, 5 and 6] can be associated with the faulting event but further palaeoseismic and historical investigations with precise dating are needed for a reliable correlation.

Event $X$ : The third faulting event visible in the trench occurred between units e and d, according to the easternmost rupture and associated shear zone buried below d. Although the step is eroded, the top stratigraphic line of unit e shows a clear displacement capped by unit d (Fig. $6 \mathrm{~b}$ ). This erosional truncation of the fault suggests a distinct palaeoseismic event and not simply a plunging tip line within the strike slip shear zone. The larger offset of unit e within the shear zone and with respect to the offset bedding in unit d, immediately below unit $\mathrm{b}$ (west branch of the fault zone) also attests for the occurrence of event $\mathrm{X}$. Radiocarbon dating of unit e and d, along with Bayesian analysis indicate that the seismic event occurred between $\mathrm{AD} 100$ and $\mathrm{AD} 750$ (Table 3). However, this event may also be correlated with the large earthquake that destroyed the ancient city of Apamea and damaged Beirut in 13 December $115[4,6]$.

In summary, Table 3 shows that the antepenultimate event $\mathrm{X}$ took place probably during the Roman occupation after $\mathrm{AD} 70$ and perhaps in $\mathrm{AD}$ 115, the penultimate event $\mathrm{Y}$ after the Byzantine period and perhaps during the early Islamic period (AD 690 - 1030) and the most recent event most likely in AD 1170.

The $13.6 \mathrm{~m}$ total horizontal offset of the aqueduct likely results from successive displacements during seismic events $\mathrm{X}, \mathrm{Y}$ and $\mathrm{Z}$ that occurred in the last 2000 years (Fig. 7). The age of the aqueduct 
bracketed between $\mathrm{AD} 30$ and $\mathrm{AD} 70$ implies a late Holocene slip rate of 6.8 to $7.0 \mathrm{~mm} / \mathrm{yr}$. along the Missyaf segment of the DSF. Furthermore, archaeoseismic and palaeoseismic data suggest a comparable coseismic slip of 4.0 to $4.5 \mathrm{~m}$ for the last three events (X, $\mathrm{Y}$ and $\mathrm{Z}$ ) consistent with an $\mathrm{M} \geq 7$ size of historical earthquakes as assigned by Ambraseys and Jackson [1]. The slip rate and mean coseismic displacement suggest an average recurrence interval for large earthquakes of 550 years, and the 830 years that have elapsed since the most recent earthquake suggest a short time left until the next large earthquake (Fig. 7).

\section{Implications of the 830-year seismic quiescence for the seismic hazard evaluation}

Historical documents show that several large earthquakes have occurred along the northern strand of the Dead Sea fault from AD 749 to 1408 (Figure 1 b). In particular, the sequence of historical earthquakes in AD 1157, 1170 and 1202 took place in continuity along three fault segments in Syria and Lebanon, with a migration toward the south in relatively short time intervals (13 and 32 years). Several fault segments are defined and among them the Missyaf fault segment that is identified as a $70 \mathrm{~km}$ long earthquake fault along the DSF.

The correlation between palaeoseismological and archaeological investigations offers an opportunity for a quasi-3D study along a seismogenic fault. Trench results and total and first displacement of the aqueduct imply a left-lateral slip per event at Al Harif site of about 4.0 to $4.5 \mathrm{~m}$. A similar amount of coseismic slip has been observed along other major continental faults, e.g. the North Anatolian fault in Turkey and related $\mathrm{M}_{\mathrm{w}}=7.3,1999$ Izmit earthquake [28]. Using scaling laws for large earthquakes [29] we obtain a range of $\mathrm{M}_{\mathrm{w}}$ between 7.0 and 7.5 for the events along the Missyaf segment. The analysis of faulting episodes and dated units in the trench reveal that 3 large seismic events have occurred in the last 2000 years (Table 3): (i) the ante-penultimate event between $\mathrm{AD} 100$ - AD 750 that may be correlated with the 13 December 115, (ii) the penultimate event between AD 690 - 1030, and (iii) the most recent event between AD 990 - 1210 that may be correlated with the large earthquake of 29 June 1170 along the DSF.

The slip rate deduced from the displaced aqueduct and trench dating ranges between $6.8-7.0$ $\mathrm{mm} / \mathrm{year}$ for the past 2000 years, and is consistent with predicted values along the northern DSF from plate motions between Arabia and Africa [12]. Recent geological investigations along the southern DSF (Wadi Araba fault zone) indicate various late Pleistocene and Holocene slip rate with $2-6 \mathrm{~mm} / \mathrm{yr}$ [9], $3.9-6$ $\mathrm{mm} / \mathrm{yr}$ [30], $10 \mathrm{~mm} / \mathrm{yr}$ [31] and $2.5 \mathrm{~mm} / \mathrm{yr}$ [32]. They denote the complex fault zone and the difficulty in 
characterising and dating offset of alluvial fan and gullies. Owing to the short time period spanned by the aqueduct, it is clear that further palaeoseismic studies that cover the Holocene and late Pleistocene time are needed for better constraining the slip rate along the DSF.

The seismic behaviour of the northern DSF appears to involve long periods of seismic quiescence punctuated by infrequent, large earthquakes. Three events are interpreted to have occurred between AD 70 and $\mathrm{AD} 1170$ (1100 years) followed by about 830 years without a major earthquake along the Missyaf segment. The $6.8-7.0 \mathrm{~mm} / \mathrm{yr}$ of slip rate at depth would accumulate a slip deficit of $5.6-5.8 \mathrm{~m}$ on the locked upper part of the fault, which exceeds the average estimated past coseismic slip (Fig. 7). Due to our single observation concerning the amount of slip at the aqueduct site and complicated fault segmentation

along strike, the rupture history of the DSF can be driven by either slip patches or characteristic slip behaviour [33]. However, a large earthquake with $\mathrm{M}>7$ along the Missyaf and adjacent fault segments would induce severe damage to the region. We interpret the seismic quiescence during the past 830 years may represent a high level of seismic hazard in Syria and Lebanon.

\section{References}

[1] N.N. Ambraseys, J. A. Jackson, Faulting associated with historical and recent earthquakes in the Eastern Mediterranean region, Geophys. J. Int. 133 (1998) 390-406.

[2] Z. Garfunkel, I. Zak, R. Freund,. Active faulting in the Dead Sea rift, Tectonophysics 80 (1981) 1-26.

[3] N.N. Ambraseys, M. Barazangi, The 1759 earthquake in the Bekaa Valley: Implications for earthquake hazard assessment in the Eastern Mediterranean Region, J. Geophys. Res. 94 (1989) 4007-4013.

[4] M. R. Sbeinati, R. Darawcheh, M. Mouty, The historical earthquake catalogue in Syria and its vicinity (BC 1365 - AD 1900), pp. 152, submitted to Annali di Geofisica.

[5] J. P., Poirier, M.A. Taher, Historical seismicity in the Near and Middle East, North Africa, and Spain from Arabic documents (VIIth - XVIIIth century), Bull. Seism. Soc. Amer. 70 (1980) 2185-2201.

[6] E., Guidoboni, Catalogue of ancient earthquakes in the Mediterranean area up to the $10^{\text {th }}$ century, in: SGA (Ed.), Istituto Nazionale di Geofisica Rome, 1994, pp 503.

[7] R.W.H. Butler, S. Spencer, H.M. Griffiths, Transcurrent fault activity on the Dead Sea Transform in Lebanon and its implications for plate tectonics and seismic hazard: J. Geol. Soc. London 154 (1997) 757-760.

[8] J. Jackson, D. McKenzie, The relationship between plate motions and seismic moment tensors, and rates of active deformation in the Mediterranean and Middle East, Geophys. J. 93 (1988) 45-73. 
[9] R. Ellenblum, S. Marco, A. Agnon, T. Rockwell, A. Boas, Crusader castle torn apart by earthquake at dawn, 20 May 1202: Geology 26 (1998) 303-306.

[10] Y. Klinger, et al. Slip rate on the Dead Sea transform fault in the northern Araba Valley (Jordan), Geophys. J. Int. 142 (2000) 755-768.

[11] F. Gomez, et al. Coseismic displacements along the Serghaya fault: An active branch of the Dead Sea fault system in Syria and Lebanon, J. Geol. Soc. London 158 (2000) $405-408$.

[12] S. McClusky, et al. GPS constraints on plate kinematics and dynamics in the eastern Mediterranean and Caucasus, J. Geophys. Res. 105 (2000) 5695-5719.

[13] R. Freund, et al. The shear along the Dead Sea rift, Phil. Trans.R. Soc.London, Series A, 267 (1970) 107-130.

[14] A. M. Quennell, The Western Arabia rift system, in: J.E. Dixon, and A.H.F. Robertson (Eds), The Geological Evolution of the Eastern Mediterranean, Blackwell Scientific, Oxford, 1984, pp. 775788.

[15] M.R. Hempton, Constraints on Arbian plate motion and extensional history of the Red Sea, Tectonics 6 (1987) 687-705.

[16] T.A., Chaimov, M., Barazangi, D., Al-Saad, T. Sawaf, A. Gebran, Crustal shortening in the Palmyride fold belt, Syria, and implications for movement along the Dead Sea fault system, Tectonics 9 (1990) 1369-1386.

[17] N. Ambraseys, C. P. Melville, Historical evidence of faulting in Eastern Anatolia and northern Syria, Annali di Geofisica 28 (1988) 337 - 343.

[18] V. G., Trifonov, Levant fault zone in northwest Syria, Geotectonics 25 (1991) 145-154.

[19] G., Brew, M., Barazangi, A.K. Al-Maleh, \& T. Sawaf, Tectonic and geologic evolution of Syria, GeoArabia 6 (2001) 573-616.

[20] S.J. Plassard, B. Kogoj, Sismicité du Liban: Catalogue des séismes ressentis, 3e édition, in: Collection des Annales-Mémoires de l'Observatoire de Ksara, tome IV (Sismologie) Cahier 1, Conseil National Libanais de la Recherche Scientifique, Beyrouth, 1981, pp. 67.

[21] A. Ben Menahem, Earthquake catalogue for the Middle East (BC 92 to AD 1980), Bol. Geof. Teor. ed Applic. 21, 1979, Trieste.

[22] A. Nur, E. H. Cline, Poseidon's Horses: Plate tectonics and earthquake storms in the late Bronze age Aegean and Eastern Mediterranean, J. of Archaeo. Sci. 27 (2000) 43-63.

[23] E. Ibn Al-Athir, The complete in history (Al-Kamil fi al-tarikh), Dar Sader (Ed.), Beirut, 1982, vol. 8, 9, 10, 11, 12.

[24] N. Ambraseys, C. P. Melville, An analysis of the eastern Mediterranean earthquake of 20 May 1202, in Historical Seismograms and Earthquakes of the World, Lee W., Academic Press (Ed.), San Diego, 1988, pp. $181-200$

[25] C. Bronk-Ramsey, Probability and Dating, Radiocarbon, 40 (1998) 461-474. 
[26] M. Stuiver, P.J. Reimer, E. Bard, J.W. Beck, G.S. Burr, K.A. Hughen, B. Kromer, G. McCormac, J. van der Plicht, M. Spurk, 1998 INTCAL9 Radiocarbon Age Calibration, 24000-0 cal BP, Radiocarbon 40 (1998) 1041-1083.

[27] G. Biasi, R. J. Weldon, Palaeoseismic date refinement and implications for seismic hazard estimation, Quat. Res. (1994) 41, 1 - 18.

[28] A. Barka, The August 1999 Izmit earthquake, Science 285 (1999) 1858 - 1859.

[29] D. Wells, K. Coppersmith, New empirical relationships among magnitude, rupture length, rupture width, rupture area, and surface displacement, Bull. Seism. Soc. Am. 84 (1994) 974-1002.

[30] T. Niemi et al., Late Pleistocene and Holocene slip rate of the Northern Wadi Araba fault, Dead Sea Transform, Jordan, J. of Seismology 5 (2001) 449-474.

[31] P. Galli, Active tectonics along the Wadi Araba-Jordan Valley, J. Geophys. Res. 104 (1999) 2777-2796.

[32] S. Marco et al., 817 year-old-walls offset sinistrally $2.1 \mathrm{~m}$ by the Dead Sea Transform, Israel, J. Geodyn. 24 (1997) 11-20.

[33] K. Sieh, The repetition of large-earthquake ruptures, Proc. Natl. Acad. Sci. 93, 1996, pp. 3764 - 3771.

\section{Acknowledgments}

This research benefited from the full field support of the Higher Institute of Applied Sciences and Technology (HIAST) in Damascus. Additionally, the Syrian Atomic Energy Commission and Damascus University provided logistical support to this project. We thank Professors Mikhail Mouty and Khaled AlMaleh (Damasus University) for their constant support during the 3-year study of the Dead Sea fault in Syria. We also thank Mrs Ghada Suleiman (DGAM, Damascus) for the assistance on the aqueduct archaeology and Mr Jean Vogt for fruitful discussions on the historical seismicity of Syria. We are grateful to Professor Pieter Grootes (Kiel University) for the radiocarbon dating results and detailed analysis of travertine. This research is partially supported by the NSF grant EAR-0106238 to Cornell University, by the UMR 7516 of CNRS in Strasbourg and the European Commission project APAME (ICA3-CT-2002-10024). 


\section{Figure captions}

Figure 1: a: Map showing the tectonic setting and instrumental seismicity from 1963 - 1997 (International Seismological Centre data file, $M>1$ ) of the study area along the Missyaf segment of the Dead Sea fault (DSF). Focal mechanisms along the DSF are of moderate earthquakes $(5<\mathrm{Mw}<6$; from $\mathrm{CMT}$ Harvard and MEDNET-INGV Rome). PFB = Palmyride fold belt, EAF = East Anatolian fault.

b: Map of fault segments interpreted from structural pattern along the northern section of the DSF and inferred ruptures of the main historical seismic events (see also Table 1) [1, 4, 6, 17], B is Beirut and D is Damascus. The historical seismicity that documents the sequence of AD 1157, 1170 and 1202 large events is based on original Arabic sources [4] [5] [6] [24]; their spatial distribution suggests a structural control of coseismic ruptures associated with a fault segmentation along the DSF.

c: Shaded topographic image from radar interferometry of the northern Dead Sea Fault; arrows denote the Missyaf fault segment which is limited by the Ghab pull apart to the north and Qalaat Al Hosn pull apart to the south; square is the location of Figure 2.

Figure 2: Morphotectonic map showing the Dead Sea fault and location of the ancient aqueduct and trench site west of the shutter ridge (in grey). Numbers denote elevation (in meter). Thick contour lines are for $50 \mathrm{~m}$ and dashed lines are for $10 \mathrm{~m}$. The shutter ridge (shaded area) indicates the fault location and related cumulative right-lateral movement. The $\sim 200 \mathrm{~m}$ deflection of the Al Harif Stream is about 40 50 times the individual coseismic displacement inferred from the aqueduct (Fig. 3).

Figure 3: a: Detailed map of the aqueduct, trench site, and surrounding area based on precise mapping with a total station (large crosses are points levelled on the aqueduct, small crosses are the background levelling points for the alluvial terrace). $13.6 \mathrm{~m}$ total left-lateral displacement is measured between straight sections of the aqueduct. The $4.3 \mathrm{~m}$ are interpreted as resulting from the first coseismic slip after building the aqueduct and after projecting the eastern wall on the fault. Additional breaks in the travertine wall (see also Fig. 4 b) and rebuilt phases inferred from two different types of building stones, and the remained fallen piece of wall near the fault attest for repeated coseismic movements (see text). 
The trench exposes the fault zone and the archeo-trench excavates the wall foundation (red area) orthogonal to the fault (Fig. 4 a).

$\mathrm{b}$ : Photograph of the aqueduct looking west. The aqueduct used to bring fresh water from the wet western high mountains to wheat and olive oil mills and local cities and villages located in the eastern plains. In foreground, the bridge allows the aqueduct to cross the El Harif River (see also Fig. 4 b). It has been faulted three times and displays a total left lateral offset of $13.6 \pm 0.2 \mathrm{~m}$ (Note the trench nearby and related log in Fig. 5 a). Radiocarbon dating of travertine accumulation and unit e below its foundation indicate that the aqueduct may be younger than $\mathrm{AD} 30$ and older than $\mathrm{AD} 70$ (see text for explanation) .

Figure 4: a - Excavation of the western section of the aqueduct (red area in Fig. 3 a) and the prominent travertine accumulation on the wall. Although a section of the wall above the ground surface is missing (stones were probably removed to construct nearby fences), the aqueduct foundation indicates a straight line (white arrows) and reaches to the east the fault trace (black arrows).

$\mathrm{b}$ - Details of the warped section at the west side of the bridge showing travertine filling ruptures and cracks of building stones (see black arrows). The excavation below the rupture (white arrow) does not show any faulting. Ruptures in travertine filling previous cracks indicate at least two episodes of deformation since the building of the aqueduct.

Figure 5: a: Photograph of the V-shaped structure of the fault zone visible in the trench walls. White string grid is spaced 1 meter. The white line indicates unit e interrupted and vertically displaced at the fault zone.

b: Trench log of the fault zone and related alluvial terrace deposits. Multiple ruptures with displacement of units b, c, d and e mark the 3 most recent faulting events at this site. Repeated small depressions (likely small pull apart basins filled by units $\mathrm{c}$ and $\mathrm{b}$ ) with coarse deposits mixed with debris flow probably from previous flood events and thickening of units $d$ and $b$ are visible in the shear zone. Black squares depict the locations of dated charcoal samples. The vertical separation visible from unit e results from cumulative movement on the fault. 
Figure 6: a - Central shear zone of the fault with vertical offset visible at the interface between units $f$ and $e$ (see also Fig. 5 b). Note the flat lying coarse gravel and pebbles of unit a, and the oriented clasts in unit b.

$\mathrm{b}-$ Event $\mathrm{X}$ shown by the fault displacement of unit e eroded (white arrows) and buried below unit $\mathrm{d}$ (black arrows show the easternmost fault branch in Fig. 5 b).

Figure 7: Cumulative left-lateral offset over the last 2000 years along the Missyaf segment of the Dead Sea Fault obtained from palaeoseismic and historical data. The succession of past earthquakes is deduced from radiocarbon dating of faulted units in trench (Fig. $5 \mathrm{~b}$ ). The first coseismic displacement $(4.3 \mathrm{~m})$ and the cumulative slip for the three events $(13.6 \mathrm{~m})$ were measured from the faulted aqueduct (Fig. $3 \mathrm{a})$. The late Holocene slip rate of $6.8-7.0 \mathrm{~mm} / \mathrm{yr}$. and mean coseismic displacement suggest an average recurrence time for large earthquakes of about 550 years. 833 years have elapsed since the last earthquake in $\mathrm{AD}$ 1170. Following a time-predictable earthquake recurrence model, the slip rate line projects from the last event to suggest that failure of this segment of the DSF fault may perhaps be imminent, or possibly overdue. 


\section{Table captions}

\section{Table 1.}

Large historical earthquakes along the northern section of the Dead Sea fault (see also Figure $1 \mathrm{~b}$ ). Surface faulting reports and a rich description of damage exist in original Arabic sources [1, 3, 4, 5, 6, 17]. Estimated magnitudes are from Ambraseys and Jackson [1]. We have interpreted the associated fault ruptures in terms of possible segmentation of the northern DSF.

\section{Table 2.}

Characteristic of radiocarbon dating of samples of the aqueduct site. All dating methods are AMS (accelerator mass spectrometer). $\mathrm{R}$ is for reworked and units are illustrated in Fig. 5 b. All samples have been calibrated using the Oxcal program v3.5 [25] and calibration curve INTCAL98 [26]. Adopted age ranges are equivalent to calibrated $2 \sigma$ ranges $(94.5 \%)$, in $\mathrm{AD}$ and $\mathrm{BC}$ and without taking into account ranges with probability of $1 \%$ and less.

\section{Table 3.}

Probability distribution of calibrated $\mathrm{C} 14$ ages (in calendar years BC/AD) obtained from sequential radiocarbon dates (BP) using Oxcal v3.5 [24] and INTCAL98 calibration curve [25]. As indicated in Table 2, calibrated dates are presented with $2 \sigma$-age range $(95.4 \%$ density). The age of the aqueduct is estimated considering unit e that predates the building (see text for explanation) and the travertine age that postdate the building. Age ranges of seismic events X (AD 100-750), Y (AD 700-1030) and Z (AD 990-1210) are determined using the Bayesian analysis (probability distribution of the ages). Arrows show our preferred ages associated with two historical large earthquakes in AD 115 and AD 1170. 


\section{Table 1}

\begin{tabular}{ccl}
\hline Date (A.D.) & M (estimated) & Areas with maximum damage and related fault segment \\
\hline 749 & $7.0-7.5$ & Southern Bekaa-Hula basin, Yammouneh-Ghab (2 events) \\
859 & $7.0-7.5$ & Antioch, Lattakia, Homs, Sergilla segment \\
1063 & $6.5-7.0$ & Qalaat Hosn (Crak), Tripoli, northern Yammouneh segment \\
1157 & $7.0-7.5$ & Apamea, Hama, Aleppo, Apamea segment \\
1170 & $\sim 7.5$ & Missyaf, Shaizar, Homs, Hama, Missyaf segment \\
1202 & $>7.5$ & Mt. Lebanon, Bekaa Valley, Hula Basin, Yemmouneh segment \\
1408 & $>7.5$ & Qalaat Blatnes, west of Aleppo, Lattakia segment \\
1759 & $\sim 7.4$ & Bekaa Valley, Anti-Lebanon, Golan Heights, Serghaya segment \\
\hline
\end{tabular}


Table 2

\begin{tabular}{|c|c|c|c|c|c|c|c|}
\hline $\begin{array}{l}\text { S a m p le } \\
\mathrm{n} \text { a } \mathrm{m} \text { e }\end{array}$ & Material & $\begin{array}{l}\text { Amount of } \\
\text { Carbon (mg) }\end{array}$ & $\Delta \mathrm{C}^{13}(\%)$ & $\begin{array}{l}\text { Radiocarbon } \\
\text { age (B P) }\end{array}$ & Unit & \multicolumn{2}{|c|}{$\begin{array}{c}\text { Calibrated age AD } \\
(-=\mathrm{BC} ; 2 \sigma \text { age range })\end{array}$} \\
\hline TA N31 & Charcoal & 2 & $-24,16$ & $874 \pm 34$ & $\mathrm{a}$ & 1030 & 1260 \\
\hline TA N23 & Charcoal & 5.9 & $-27,90$ & $1013 \pm 36$ & $\mathrm{c}$ & 960 & 1060 \\
\hline TA S33 & Charcoal & 4.3 & $-25,90$ & $1237 \pm 36$ & d & 680 & 890 \\
\hline TA N25 & Charcoal & 2 & $-22,95$ & $2091 \pm 50$ & e & -210 & 30 \\
\hline TA S7 & Charcoal & - & $-25,5$ & $2195 \pm 40$ & e & -390 & -160 \\
\hline TA N21 & Charcoal & 0.3 & $-33,06$ & $2718 \pm 73$ & $d-R$ & -1010 & -791 \\
\hline TA N27 & Charcoal & 4,1 & $-23,61$ & $2337 \pm 31$ & $\mathrm{f}$ & -520 & -350 \\
\hline TA N47 & Charcoal & 1,7 & $-25,93$ & $7409 \pm 46$ & $\mathrm{f}$ & -6395 & -6095 \\
\hline TA N61 & Charcoal & 1 & $-26,52$ & $4553 \pm 42$ & $\mathrm{~b}-\mathrm{R}$ & -3490 & -3098 \\
\hline $\operatorname{TrB} 13$ & Travertine & 3.7 & -28.57 & $1880 \pm 25$ & Aqueduct & 70 & 230 \\
\hline TrD5 & Travertine & 1.1 & -27.97 & $1865 \pm 30$ & Aqueduct & 80 & 240 \\
\hline
\end{tabular}




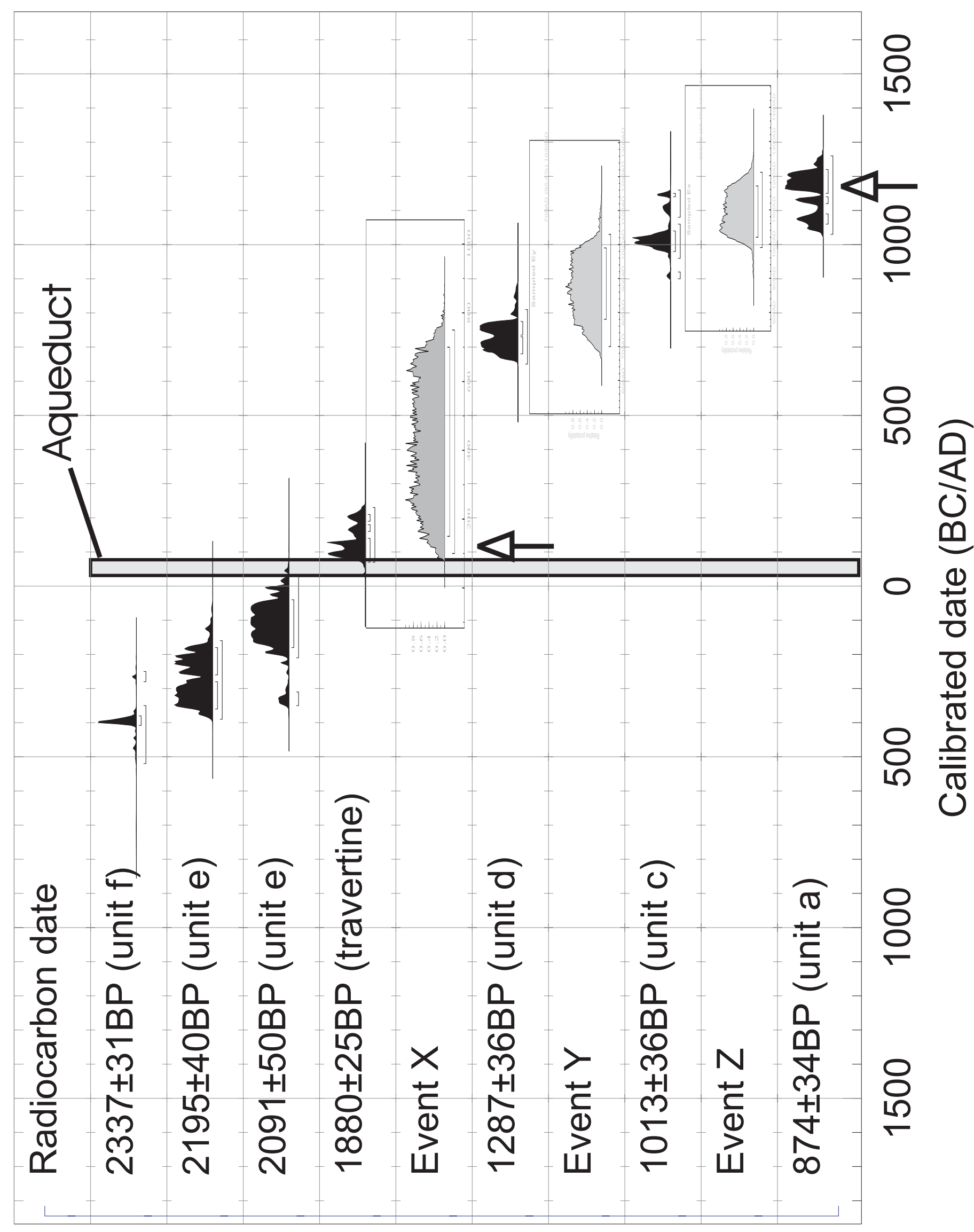




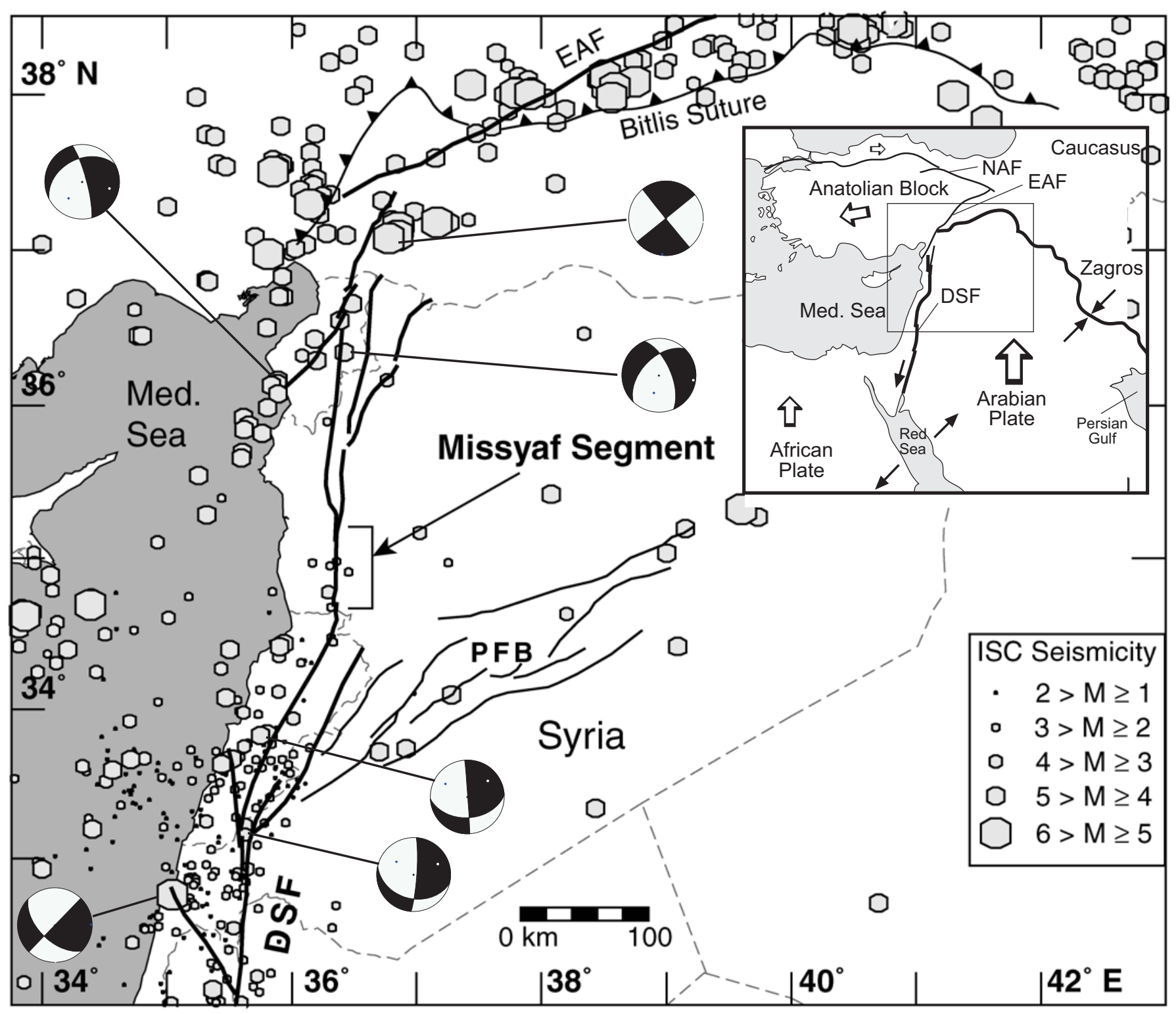

Figure 1a 


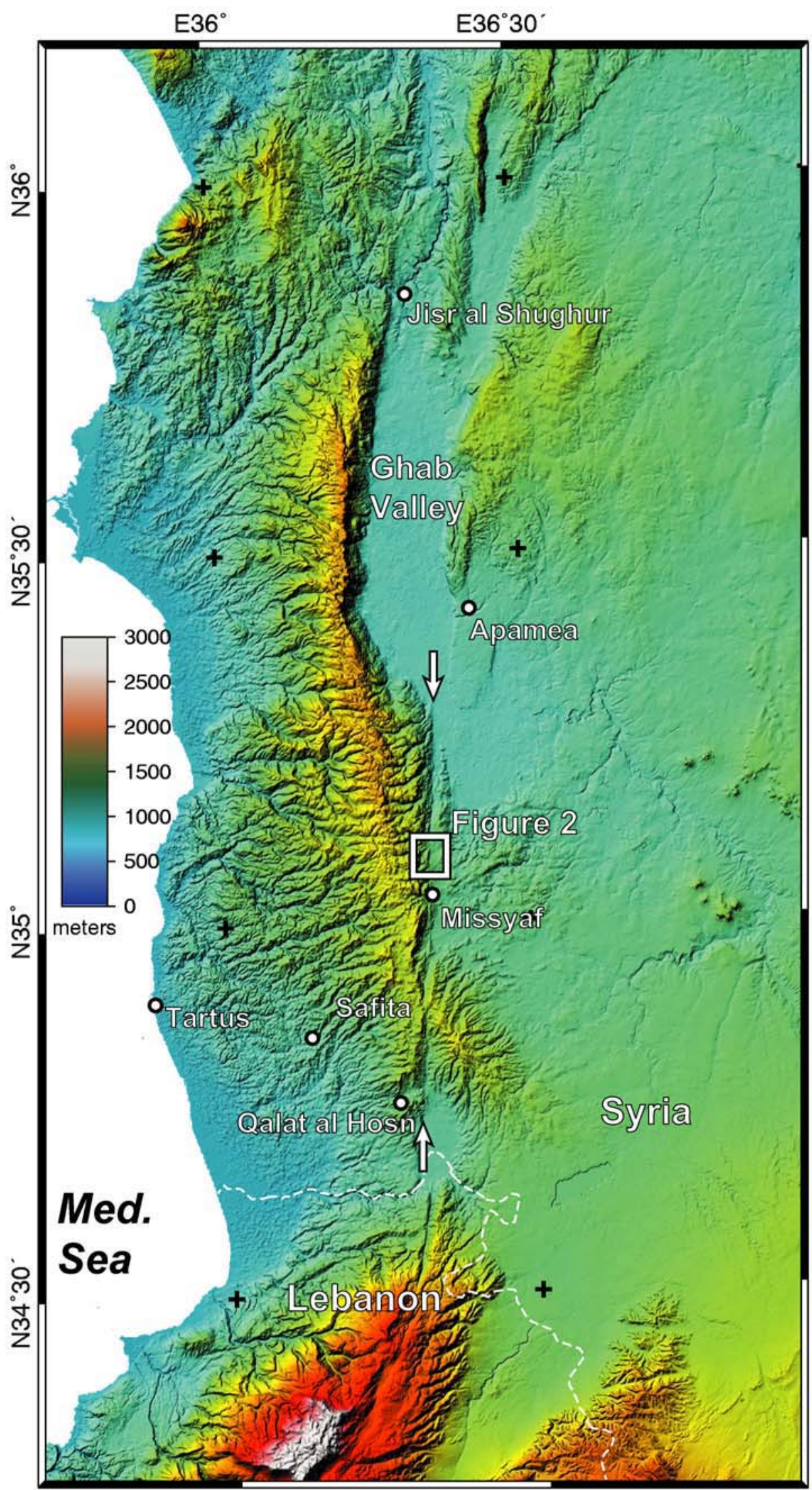

Figure 1c 
Figure 3a

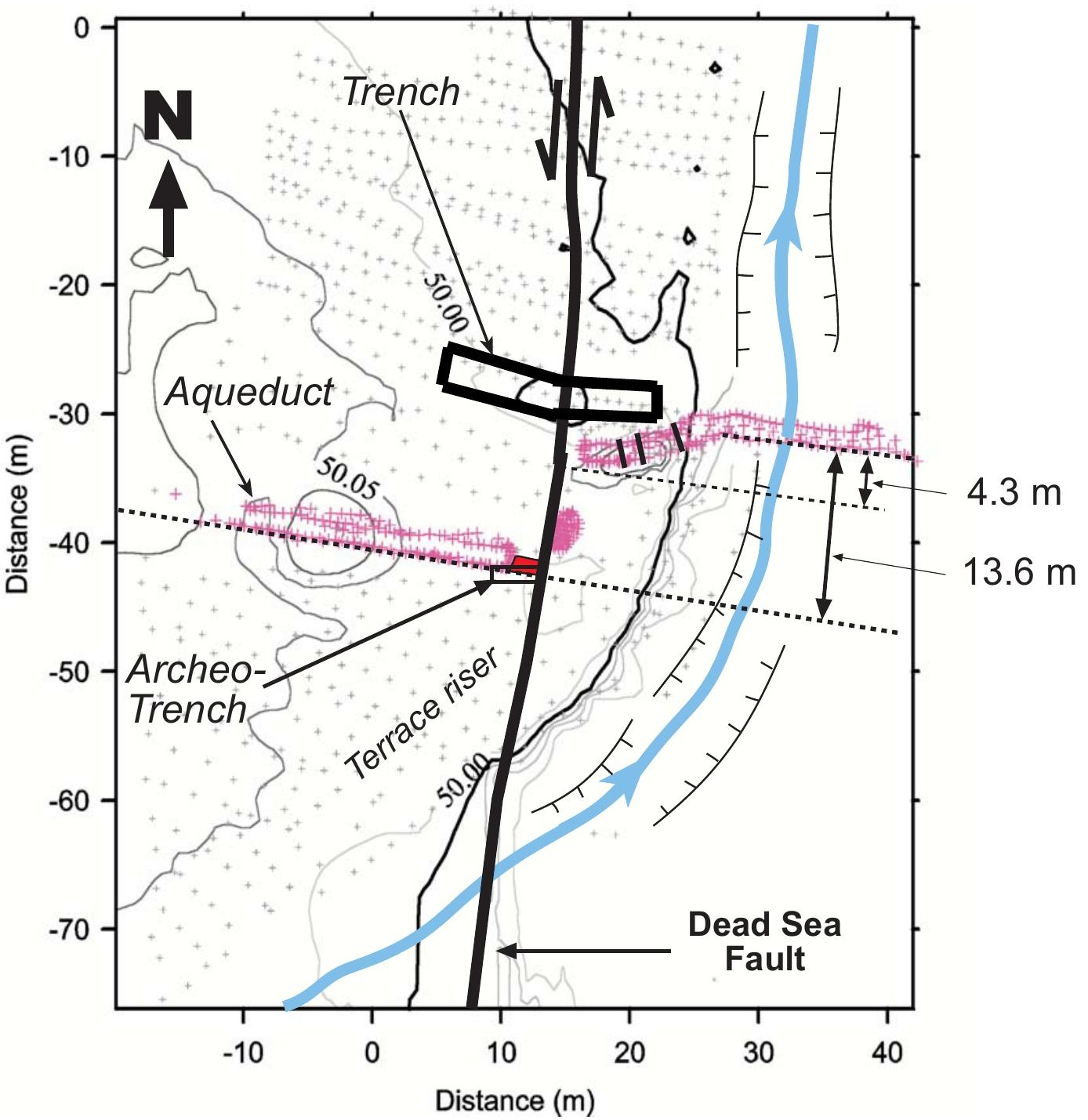




\section{Figure $4 \mathrm{~b}$}

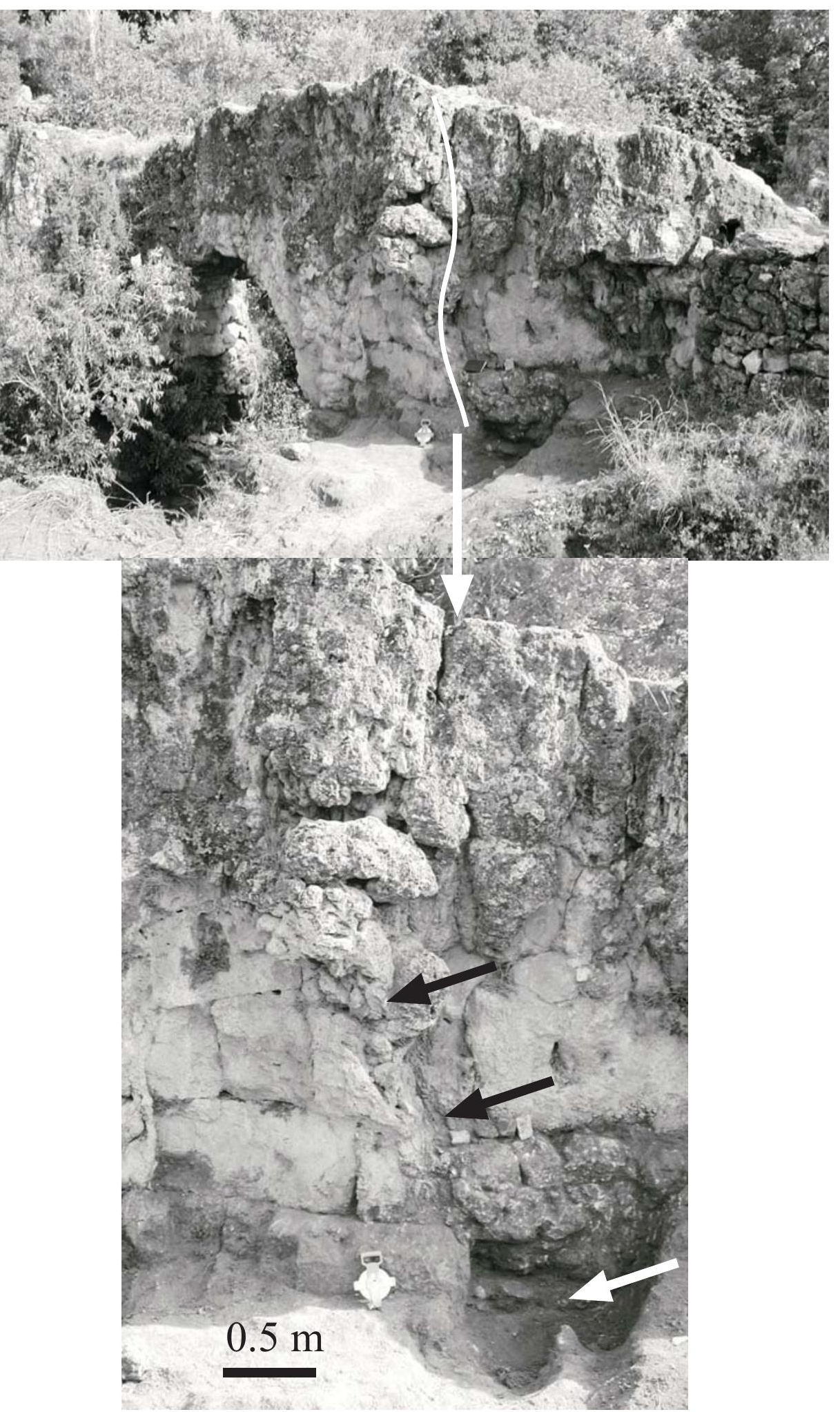


FIGURE 5 a

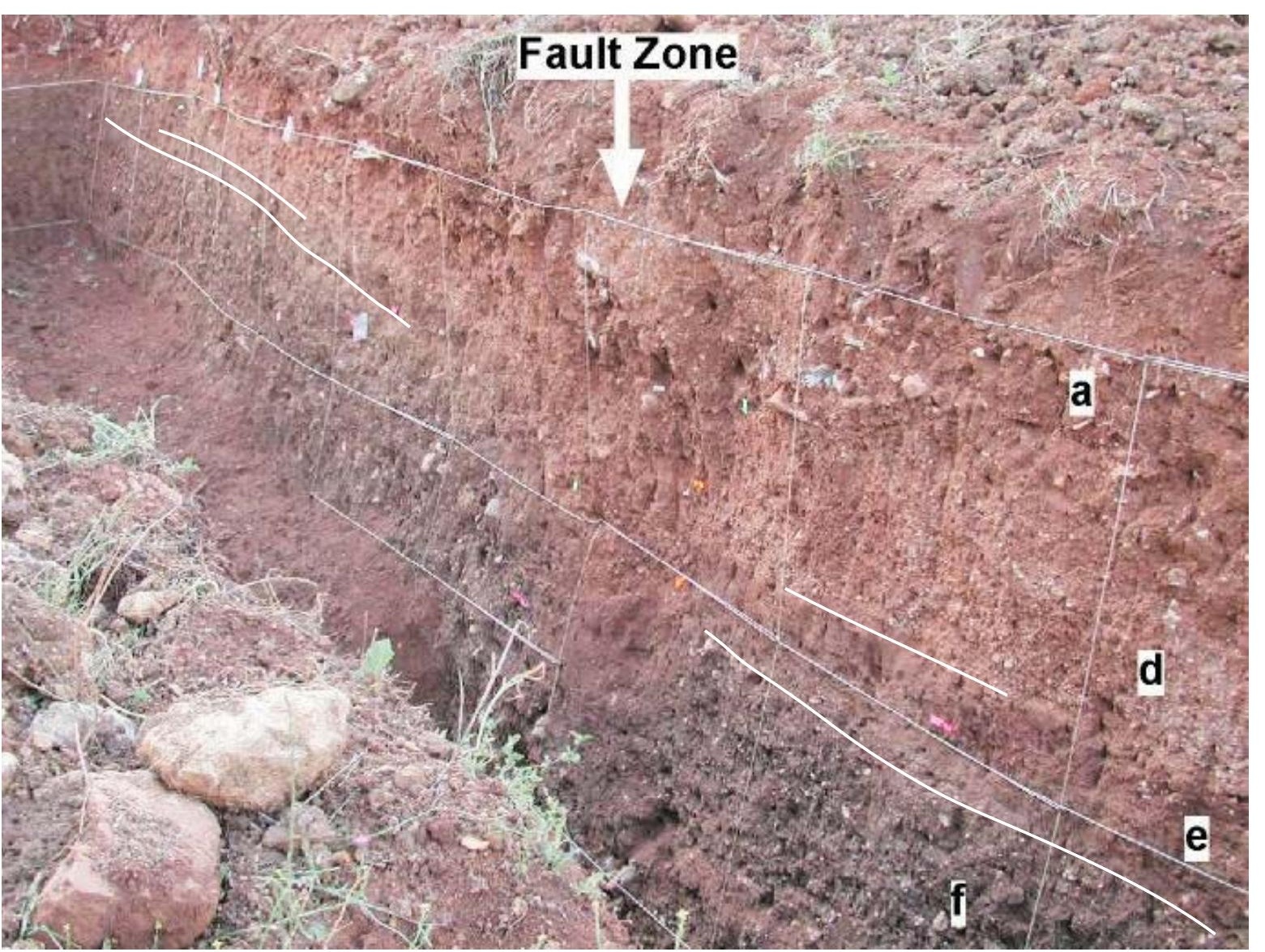




\section{Figure $6 \mathrm{~b}$}

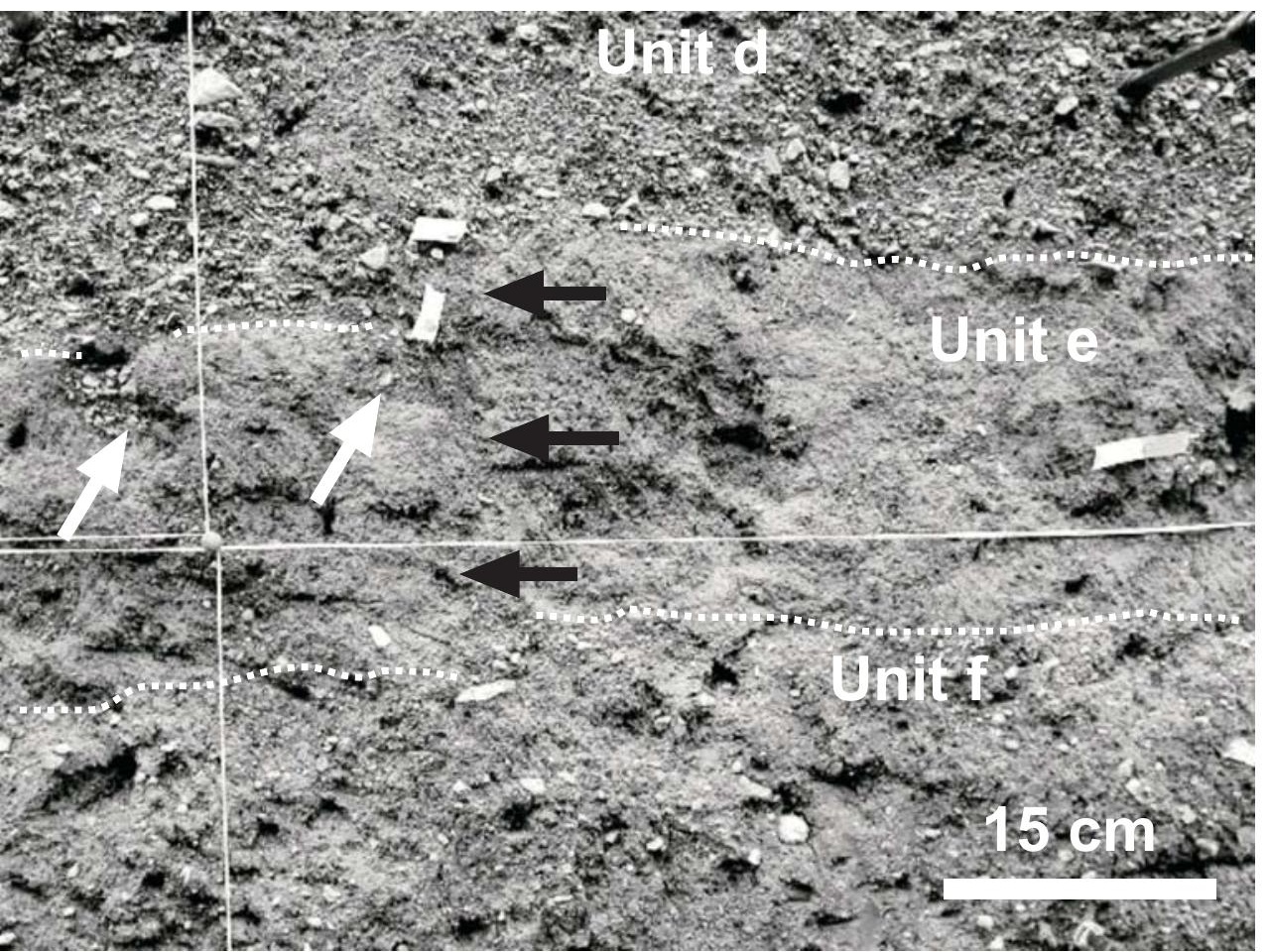


Figure 7

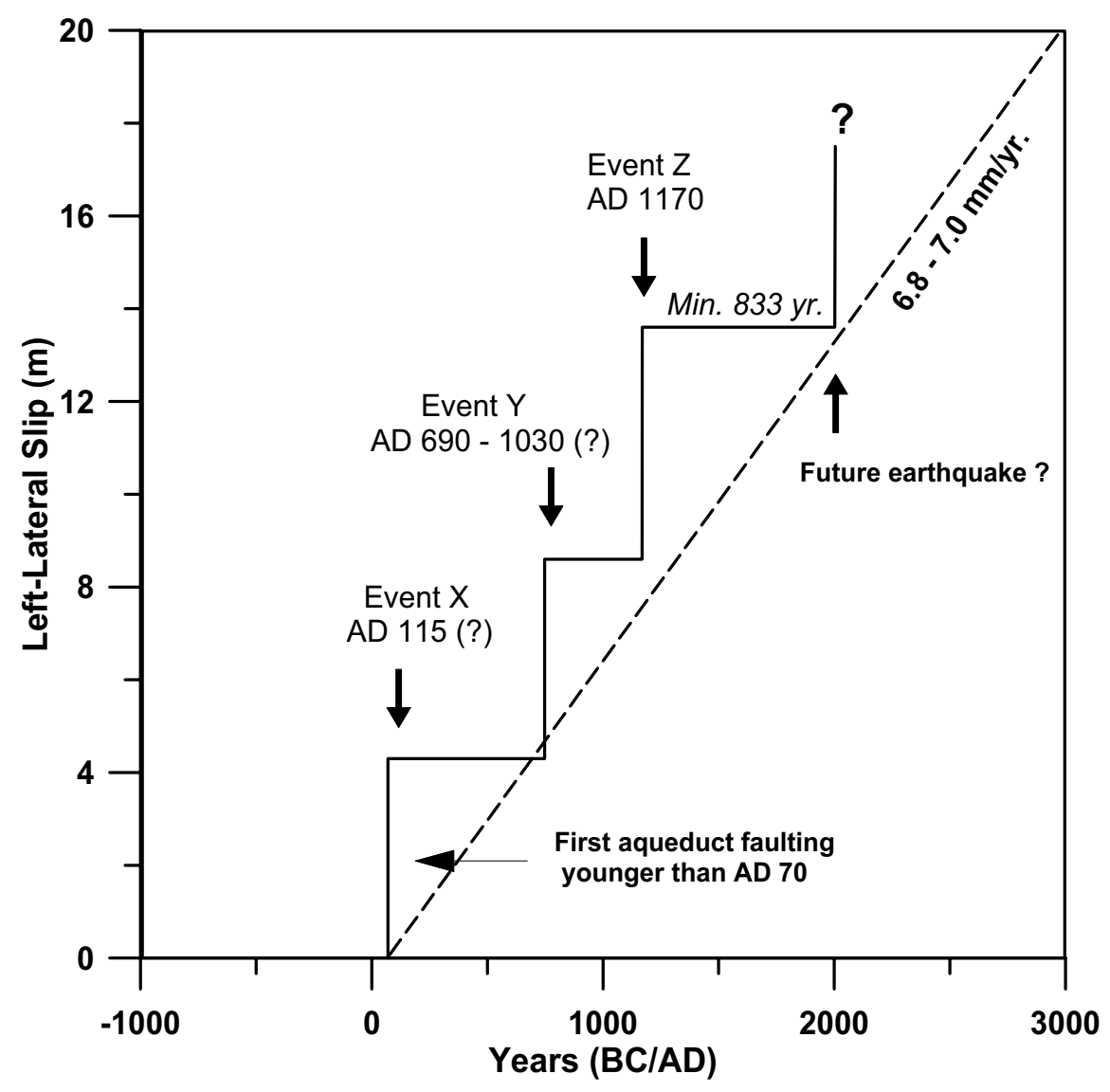

